\title{
PENGARUH PERENCANAAN PAJAK DAN KECAKAPAN MANAJERIAL TERHADAP MANAJEMEN LABA
}

\author{
Kodriyah \\ kodriyahunsera@gmail.com \\ Universitas Serang Raya \\ Ririn Fitriani Putri \\ putririn95@gmail.com \\ Universitas Serang Raya
}

\begin{abstract}
ABSTRAK
Penelitian ini bertujuan untuk mengetahui pengaruh Perencanaan Pajak dan Kecakapan Manajerial terhadap praktek Manajemen Laba. Penelitian ini menggunakan purposive sampling sehingga diperoleh sampel 10 perusahaan manufaktur sub sektor pertambangan yang memenuhi kriteria selama tahun 2011-2015 yang terdaftar BEI. Metode analisis yang digunakan dalam penelitian ini adalah analisis regresi berganda dan diolah menggunakan program SPSS 20. Hasil dari penelitian ini menemukan bahwa variabel Perencanaan Pajak memiliki pengaruh signifikan terhadap Manajemen Laba, hal ini menunjukkan semakin tinggi perencanaan pajak maka semakin besar peluang perusahaan melalukan manajemen laba. Dan variabel Kecakapan Manajerial tidak memiliki pengaruh yang signifikan terhadap Manajemen Laba laba hal ini dikarenakan manajer yang cakap tidak akan melakukan manajemen laba untuk memperbagus laba. Manajer yang cakap mampu mengambil keputusan-keputusan ekonomi yang tepat dan mampu mencapai tingkat efisiensi yang tinggi dalam mengelola sumber daya perusahaan sehingga memperoleh laba yang maksimal sesuai tujuan yang diharapkan oleh pemilik modal.
\end{abstract}

Kata Kunci : Perencanaan Pajak, Kecakapan Manajerial, Manajemen Laba, Data Envelopment Analysis (DEA)

\section{ABSTRACT}

This research aims to determine the effect of tax planning, and managerial skills on earnings management practices. This researsh uses purposive sampling so that a sample of 10 mining sub-sector manufacturing companies is obtained that meet the criteria during the year 2011-2015 that are listed on the IDX. The analytical method used in this study is multiple regression analysis and processed using the SPSS 20 program. This research found that the quality of tax planning have a significant influence on earnings management, this shows that the higher the tax planning, the greater the chances of the company to do earnings management. And the managerial skills have no significant effect on earnings management because qualified managers will not make earnings management to improve profits. Skilled managers are able to take the right economic decisions and are able to achieve a high level of efficiency in managing company resources so as to obtain maximum profits in accordance with the objectives expected by the owners of capital.

Keywords: Tax Planning, Managerial Skills, Earning Management, Data Envelopment Analysis (DEA)

\section{PENDAHULUAN}

Laporan keuangan merepresentasikan pilihan metode-metode akuntansi yang digunakan perusahaan, metode akuntansi yang digunakan akan disesuaikan dengan tujuan perusahaan. Peraturan tentang pelaporan keuangan dan akuntansi telah memberikan peluang 
untuk melakukan manajemen laba, contohnya seperti fleksibilitas tentang metode - metode akuntansi yang berbeda. Menurut PSAK 16 revisi 2011 tentang pengakuan dan pengukuran aset tetap, terdapat beberapa pilihan atau alternatif perlakuan akuntansi. Karena itu, penelitian tentang manajemen laba telah mendapat perhatian dari berbagai pihak yang memiliki kepentingan dengan transaksi perusahaan. Tindakan campur tangan manajemen terhadap laporan keuangan dapat mengurangi kepercayaan masyarakat terhadap pelaporan keuangan. Manajemen laba juga dapat mempengaruhi kualitas laporan keuangan, selain itu, manajemen laba mengakibatkan investor tidak mendapatkan infornasi yang sebenarnya.

Perencanaan pajak merupakan langkah awal dalam manajemen pajak. Pada umumnya penekanan perencanaan pajak (tax planning) adalah untuk meminimumkan kewajiban pajak. Tujuan perencanaan pajak adalah merekayasa agar beban pajak (tax burden) dapat ditekan serendah mungkin dengan memanfaatkan peraturan yang ada tetapi berbeda dengan tujuan pembuat undang-undang, maka perencanaan pajak disini sama dengan tax avoidance karena secara hakikat ekonomis keduanya berusaha untuk memaksimalkan penghasilan setelah pajak karena pajak merupakan unsur pengurangan laba yang tersedia, baik untuk dibagikan kepada pemegang saham maupun untuk diinvestasikan kembali. Untuk meminimumkan kewajiban pajak dapat dilakukan dengan berbagai cara, baik yang masih memenuhi ketentuan perpajakan maupun yang melanggar peraturan perpajakan. Pihak manajemen menginginkan pembayaran pajak sekecil mungkin, dengan demikian para manajer biasanya melakukan cara untuk meminimalkan beban pajak yang akan dibayar pihak manajemen dengan cara mengelola utang pajaknya.

Faktor lainnya yang mempengaruhi manajemen laba adalah kecakapan manajerial. Kesadaran manajemen akan pentingnya informasi laba mendorong manajer untuk melakukan intervensi dalam proses pelaporan keuangan demi mencapai tujuan tertentu. Adanya ketidaksejajaran kepentingan antara pemegang saham dengan manajer (masalah keagenan). Baik pemilik maupun manajer merupakan individu yang cenderung mencari keuntungan sendiri. Masalah keagenan ini mengakibatkan adanya sifat manajemen melaporkan laba secara oportunistik untuk memaksimumkan kepentingan pribadinya. Perhatian pengguna laporan keuangan yang lebih terpusat pada informasi laba dan adanya ketidaksejajaran kepentingan antara manajer dengan pihak pengguna laporan keuangan yang lain mendorong manajer untuk melakukan manajemen laba.

\section{Kerangka Teoritis dan Pengembangan Hipotesis \\ Manajemen Laba}

Manajemen laba sebagai suatu intervensi manajemen dengan sengaja dalam proses penentuan laba untuk memperoleh beberapa keuntungan pribadi (Sumomba dan Hutomo, 2012). Maksud dari intervensi di sini adalah upaya yang dilakukan oleh manajer untuk mempengaruhi informasi-informasi dalam laporan keuangan dengan tujuan untuk mengelabui stakeholders yang ingin mengetahui kinerja dan kondisi perusahaan. Sering kali proses ini mencakup mempercantik laporan keuangan (fashioning accounting reports), terutama angka yang paling bawah, yaitu laba.

Manajemen melakukan manajemen laba agar laporan keuangan perusahaan terlihat lebih baik. Hal ini dikarenakan kecenderungan investor untuk melihat laporan keuangan dalam menilai suatu perusahaan. Pada umumnya investor lebih tertarik pada kinerja keuangan perusahaan di masa datang dan akan menggunakan laba yang dilaporkan pada saat ini untuk meninjau kembali kemungkinan apa yang akan terjadi di masa yang akan datang.

Manajemen melakukan peningkatan laba melalui kebijakan akrual yang dapat dideteksi dari 4 item akrual, yaitu biaya amortisasi, peningkatan net accounts receivable, 
peningkatan inventory, dan penurunan accounts payable and accrual liabilities. Biaya amortisasi merupakan akrual non-diskresi, diasumsikan bahwa kebijakan mengenai amortisasi adalah given. Peningkatan piutang dagang diasumsikan berasal dari penurunan penyisihan piutang (allowance for doubtful account) yang merupakan hasil dari estimasi yang kurang konservatif (Kodriyah dan Garnis, 2016)

\section{Discretionary Accrual}

Dalam akuntansi dikenal dengan istilah basis akrual dan basis kas. Pendekatan yang sering digunakan adalah pendekatan akrual, akuntansi akrual dianggap lebih baik daripada akuntansi berbasis kas karena akrual adalah suatu metode perhitungan penghasilan dan biaya dalam arti penghasilan diakui pada waktu diperoleh dan biaya diakui pada waktu terhutang.

Penyajian laporan keuangan yang disusun berdasarkan akrual basis berpengaruh pada transaksi dan peristiwa lain yang diakui pada saat kejadian (bukan pada saat kas atau setara kas diterima atau dibayar) dan dicatat dalam catatan akuntansi serta dilaporkan dalam laporan keuangan pada periode yang bersangkutan. Model akrual melibatkan perhitungan total akrual. Kelemahan model akrual adalah menganggap keseluruhan akrual ditimbulkan oleh manajemen laba yang dilakukan oleh manajemen, padahal kenyataannya sebagian akrual perusahaan juga disebabkan oleh kegiatan operasional dan tidak menggambarkan manajemen laba.

Discretionary Accrual adalah pengakuan akrual laba atau beban yang bebas tidak diatur dan merupakan pilihan kebijakan manajemen. Akrual yang muncul akibat diskresi manajemen atau berada di bawah kebijakan manajemen. Hal ini biasanya digunakan sebagai pengukur dalam manajemen laba dan besarannya merupakan hasil modifikasi angka-angka pada laporan keuangan untuk memenuhi tujuan manajemen sehingga keberadaan discretionary accrual menandakan rendahnya kualitas laba. Efek dari kualitas laba yang rendah adalah tidak adanya nilai prediktif dari laba, yang berarti informasi mengenai laba perusahaan ini tidaklah menggambarkan keadaan sesungguhnya dari perusahaan sehingga informasi laba menjadi bias bagi penggunanya.

\section{Perencanaan Pajak}

Perencanaan pajak digunakan oleh perusahaan untuk meminimalkan pembayaran pajak perusahaan. Untuk mendapatkan keuntungan pajak, perusahaan berupaya melakukan perencanaan pajak yang baik. Perencanaan pajak yang baik cenderung akan mengurangi laba bersih perusahaan (Wijaya dan Martani, 2011).

Perencanaan pajak merupakan tindakan penstrukturan yang terkait dengan konsekuensi potensi pajaknya, yang tekanannya kepada pengendalian setiap transaksi yang ada konsekuensi pajaknya, tujuannya adalah bagaimana pengendalian tersebut dapat mengefisienkan jumlah pajak yang akan di transfer ke pemerintah, melalui apa yang disebut penghindaran pajak (tax avoidance) yang merupakan perbuatan legal yang masih dalam ruang lingkup peraturan perundang-undangan pajak dan bukan penyelundupan pajak (Sumomba dan Hutomo, 2012).

Sedangkan Aditama dan Purwaningsih (2014) mendefinisikan perencanaan pajak (tax planning) sebagai proses mengorganisasi usaha wajib pajak atau sekelompok wajib pajak sedemikian rupa sehingga utang pajak,baik PPh maupun beban pajak yang lainnya berada pada posisi yang seminimal mungkin.

\section{Aspek-aspek Perencanaan Pajak}


Suandy (2003) menjelaskan beberapa alternative untuk mengolah variable-variabel kritis yang terkait perencanaan pajak, yakni melalui aspek-aspek:

a. Proyeksi pajak, yakni perencanaan pajak dapat dilakukan melalui suatu proyeksi. Proyeksi pajak ini dapat berupa proyeksi arus kas, laba rugi, atau proyeksi atas rencana-rencana perusahaan.

b. Bentuk usaha, yakni bentuk usaha juga berpengaruh pada bentuk pemungutan pajak, bentuk usaha contohnya: PT, Koperasi, CV dengan modal yang terdiri dari saham, firma, persekutuan atau perorangan.

c. Bidang usaha, yakni bidang usaha tertentu yang memperoleh perlakuan perpajakan yang berbeda, misalnya untuk perusahaan kontruksi

d. Pengawasan atau pemeriksaan pajak

Direktorat jendral pajak akan melakukan pemeriksaan pajak dengan tujuan untuk :

1. Menetapkan pajak-pajak negara terhutang.

2. Menetapkan besarnya kerugian yang dapat dikompensasikan dengan saldo laba tahun berikutnya.

e. Kebijakan Akuntansi

1. Penilaian persediaan, yakni kebijakan akuntansi mengenai persediaan mensyaratkan mengunakan FIFO atau Average Method, sedangkan LIFO tidak diperkenankan dalam ketetapan perpajakan. Sesuai dengan Undang-Undang No. 7 tahun 1983 tentang pajak penghasilan sebagaimana yang telah beberapa kali diubah dan terakhir disebut UndangUndang No. 36 tahun 2008 selanjutnya dalam tulisan ini disebut Undang-Undang No. 36 tahun 2008 yaitu pasal 10 ayat 6 adalah "persediaan dan pemakaian persediaan untuk perhitungan harga pokok dinilai dengan harga perolehan yang dilakukan secara rata-rata atau dengan cara mendahulukan persediaan yang diperoleh pertama".

Sewa guna usaha, yakni sewa guna usaha (leasing) aktiva tetap juga sangat menguntungkan dari segi beban pembayaran angsuran. Dari segi pemajakan, aktiva tetap sewa guna usaha tidak boleh disusutkan, tetapi beban angsuran lebih besar dari beban penyusutan, maka pembebanan pajaknya dapat menjadi lebih kecil.

\section{Kecakapan Manajerial}

Kecakapan manajerial/managerial competency adalah suatu keterampilan atau karakteristik personal yang membantu tercapainya kinerja yang tinggi dalam tugas manajemen (Puspita dan Kusumaningtyas , 2017). Demerijan, dkk. (2006) meneliti tentang kecakapan manajerial di bidang keuangan, yaitu seberapa efisien sebuah perusahaan dalam bidang keuangan secara relatif terhadap perusahaan lain. Manajer yang memiliki tingkat kecakapan yang tinggi akan lebih terampil mengolah informasi, terdapat dua hal yang menjadi pendorong manajer melakukan manajemen laba. Dua hal tersebut adalah kompensasi bonus dan asimetri informasi antara manajemen dan pemilik perusahaan.

Manajer dalam mengambil keputusan bisnis seharusnya dipandu oleh explicit profesional codes atau implicit ethics code sehingga setiap keputusan yang diambil oleh manajer selalu melalui pertimbangan profesionalnya. Manajer dan pemilik perusahaan memiliki tingkat informasi yang berbeda, manajer memiliki informasi yang lebih dibanding pemilik perusahaan tentang aktivitas bisnis perusahaan. Manajer yang memiliki keahlian akan dengan mudah menyalahgunakan dan memanipulasi informasi yang tidak diketahui pemilik dengan melakukan tindakan oportunistik. Manajer dapat melihat peluang dalam bidang akrual, akrual merupakan keputusan bidang keuangan yang diestimasi dan ditentukan oleh manajer, sehingga dengan keterbatasan informasi yang dimilki pemilik, manajer akan dengan mudah melakukan manajemen laba. Fleksibilitas dari standar akuntansi yang 
memperbolehkan manajemen untuk memilih satu dari beberapa alternatif yang tersedia juga menjadi pendorong bagi manajer yang handal untuk melakukan manipulasi.

\section{DEA (Data Envelopment Analysis)}

DEA (Data Envelopment Analysis) biasanya dinyatakan dalam Decision Making Unit atau Unit Kegiatan Ekonomi (UKE). DEA merupakan alat yang digunakan untuk mengukur efisiensi relatif suatu organisasi. Efisiensi UKE dapat diketahui dengan membandingkan efisiensi UKE suatu perusahaan dengan UKE dari perusahaan lainnya dalah suatu satuan populasi atau sempel. Namun terdapat syarat bahwa jenis input dan outputnya sama.

UKE dinilai efisien apabila rasio perbandingan input/output sama dengan 1 atau $100 \%$. Maksudnya adalah UKE tersebut mampu memanfaatkan inputnya secara maksimal untuk menghasilkan output tertentu dan tidak lagi melakukan pemborosan sehingga mampu mencapai titik yang efisien. Sedangkan UKE yang tidak efisien apabila rasio perbandingan antara input/output adalah antara $0 \leq$ input/output $<1$ atau nilainya kurang dari $100 \%$. hal tersebut berarti perusahaan belum mampu mengelola input-input yang dimilikinya untuk menghasilkan output yang optimal atau masih melakukan pemborosan dalam menggunakan inputnya (Isnugrahadi, 2009).

\section{Kerangka Pemikiran}

Berdasarkan hubungan teoritis antara variabel-variabel perencanaan pajak dan kecakapan manajerial terhadap manjemen laba, maka kerangka pemikiran dalam penelitian ini akan tampak seperti yang terdapat dalam gambar 2.1 berikut ini :

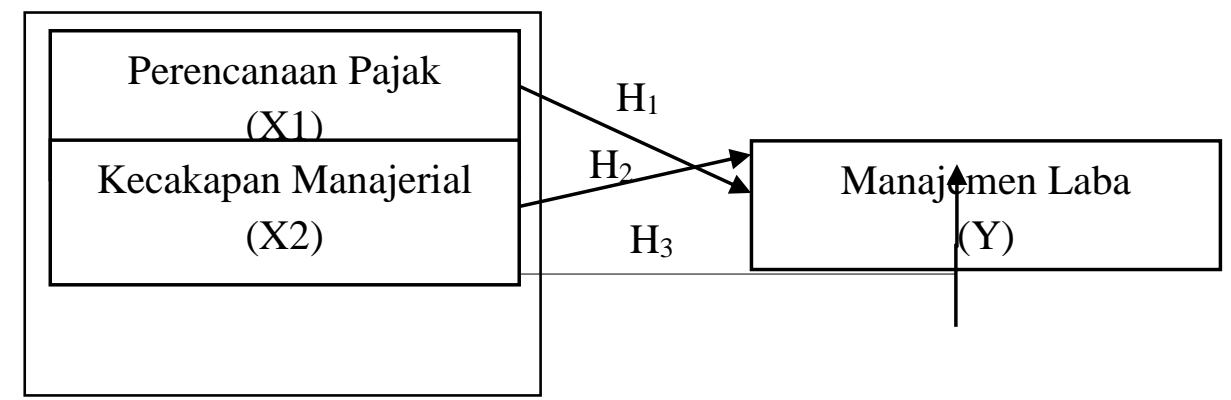

\section{Gambar 2.1 \\ Kerangka Pemikiran}

\section{Hipotesis}

Hipotesis dari penelitian yang akan dilakukan berdasarkan permasalahan dan tujuan yang telah dibahas sebelumnya dapat diuraikan sebagai berikut :

\section{Pengaruh Perencanaan Pajak Terhadap Manajemen Laba}

Untuk melakukan manajemen pajak salah satu yang dapat dilakukan yaitu dengan cara perencanaan pajak. Perencanaan pajak biasanya dilakukan perusahaan dengan tujuan menimalkan jumlah pajak yang akan dibayarkan. Menurut Sumomba dan Hutomo (2012) meneliti tentang pengaruh perencanaan pajak terhadap praktik manajemen laba, dengan hasil menunjukan bahwa perencanaan pajak berpengaruh terhadap praktik manajemen laba yang dilakukan oleh perusahaan.

Penelitian yang dilakukan oleh Wijaya dan Martani (2011) dengan judul praktik manajemen laba perusahaan dalam menggapai penurunan tarif pajak sesuai UU No 36 tahun 
2008. Dari hasil penelitian tersebut membuktikan bahwa perencanaan pajak berpengaruh signifikan dan berhubungan negatif terhadap praktik manajemen laba. Hal ini disebabkan karena adanya perubahan UU pajak penghasilan tahun 2008.

Berdasarkan uraian di atas dapat diturunkan hipotesis sebagai berikut :

\section{$H_{1}$ : Perencanaan Pajak berpengaruh terhadap Manajemen Laba}

\section{Pengaruh Kecakapan Manajerial Terhadap Manajemen Laba}

Laba dalam akuntansi dimaknai sebagai dasar pengukur kinerja perusahaan dan managemen. Demerjian dkk (2006) menguji pengaruh kecakapan managerial terhadap kualitas laba. Kecakapan managerial yang dimaksud di dalam penelitian tersebut adalah kecakapan managerial dalam bidang keuangan, yaitu seberapa efisien sebuah perusahaan dalam bidang keuangan secara relatif terhadap perusahaan lain dalam industri yang sama. Tingkat keefisienan relatif sebuah perusahaan ini dinisbahkan sebagai hasil dari kecakapan seorang manager. Hasil dari penelitan Demerjian dkk (2006) menemukan hubungan positif antara kecakapan managerial dengan kualitas laba. Dengan kata lain semakin cakap seorang manager maka laba yang dihasilkan semakin berkualitas.

Integritas manajemen yang tinggi juga diperlukan untuk menghindari praktik manajemen laba, karena manajer yang cakap dianggap memiliki kemampuan, integritas dan pengalaman sehingga dapat mengambil keputusan yang tepat demi tercapainya tujuan (Puspita dan Kusumaningtyas, 2017).

Prasyarat lain yang akan menjamin managemen selalu mendasarkan tindakannya demi kepentingan para pemegang saham adalah apabila manager dan pemegang saham memiliki informasi dengan jumlah dan kualitas yang sama. Dalam dunia nyata, manager sebagai pengelola perusahaan memiliki informasi yang lebih beragam dan lebih baik kualitasnya dibandingkan dengan para pemegang saham. Tindakan manager juga tidak dapat diamati oleh para pemegang saham. Pada kondisi ini manager memiliki informasi tersembunyi yang bisa dieksploitasi demi kepentingan pribadi manager. Perilaku oportunistis ini misalnya adalah perekayasaan pelaporan kinerja keuangan perusahan agar mendapatkan bonus yang besar. Pada perilaku oportunistis seperti ini, seorang manager yang cakap yang paham akan kondisi bisnis perusahaannya akan bisa melihat peluang dari komponen akrual yang ada untuk memaksimalkan bonusnya.

Dari paparan di atas dapat dikemukakan bahwa managemen tampaknya sulit untuk terbebas dari kepentingan pribadi dalam memilih metoda akuntansi. Hal ini ditambah dengan adanya fleksibilitas dari standar akuntansi yang memperbolehkan managemen untuk memilih satu dari beberapa alternatif yang tersedia. Pada saat yang sama terjadi asimetri informasi yang mendorong managemen untuk melakukan rekayasa laba. Seorang manager handal yang termotivasi untuk melakukan tindakan oportunistis, akan lebih mampu untuk memanfaatkan peluang-peluang yang ada untuk melakukan managemen laba. Hal ini mendorong penulis untuk mengajukan hipotesis sebagai berikut:

\section{$\mathrm{H}_{2}$ : Kecakapan Managerial berpengaruh terhadap Manajemen Laba}

\section{Pengaruh Perencanaan Pajak Dan Kecakapan Manajerial Terhadap Manajemen Laba}

Untuk melakukan manajemen pajak salah satu yang dapat dilakukan yaitu dengan cara perencanaan pajak. Perencanaan pajak biasanya dilakukan perusahaan dengan tujuan menimalkan jumlah pajak yang akan dibayarkan.

Laba dalam akuntansi dimaknai sebagai dasar pengukur kinerja perusahaan dan manajemen. Demerjian dkk (2006) menguji pengaruh kecakapan manajerial terhadap kualitas laba. Kecakapan manajerial yang dimaksud di dalam penelitian tersebut adalah kecakapan 
manajerial dalam bidang keuangan, yaitu seberapa efisien sebuah perusahaan dalam bidang keuangan secara relatif terhadap perusahaan lain dalam industri yang sama. Tingkat keefisienan relatif sebuah perusahaan ini dinisbahkan sebagai hasil dari kecakapan seorang manager.

Berdasarkan uraian pengembangan hipotesis penelitian yang telah dibuat di atas, maka penulis merumuskan hipotesis penelitian secara simultan sebagai berikut:

$H_{3}$ : Diduga Perencanaan Pajak dan Kecakapan Manajerial berpengaruh secara simultan terhadap Manajemen Laba

\section{Metode Penelitian}

Populasi dalam penelitian ini mengambil data perusahaan pertambangan yang terdaftar di Bursa Efek Indonesia periode 2011-2015 sebanyak 41 perusahaan dan pengambilan sampel menggunakan kriteria 1) Perusahaan dalam sampel adalah perusahaan pertambangan yang terdaftar di BEI untuk periode 2011-2015, 2) Informasi yang meliputi total aktiva, pendapatan, piutang dagang, persediaan, aktiva tetap, cost of goods sold, aliran kas bersih dari operasi dan jumlah tenaga kerja dan 3) Perusahaan yang tidak mengalami kerugian dalam periode 2011-2015. Berdasarkan kriteria tersebut diperoleh sampel sebanyak 10 perusahaan.

\section{Variabel dan Pengukurannya}

Discretionary accruals adalah suatu cara untuk mengurangi pelaporan laba yang sulit dideteksi melalui manipulasi kebijakan akuntansi yang berkaitan dengan akrual (Scott 2003). Pengukuran discretionary accruals sebagai manajemen laba menggunakan Model Jones Modifikasin. Untuk menghitung nilai discretionary accuals dilakukan dengan langkahlangkah sebagai berikut:

1. Menghitung total acruals dengan persamaan berikut:

\section{$\mathbf{T A C}=\mathbf{N I}_{\mathbf{i t}}-\mathbf{C F O}_{\mathrm{it}}$}

Keterangan:

$\mathrm{NI}_{\mathrm{it}}$ : laba bersih (net income) perusahaan i pada tahun $\mathrm{t}$

$\mathrm{CFO}_{\text {it }}$ : arus kas dari kegiatan operasi perusahaan i pada tahun $\mathrm{t}$

2. Meghitung nilai accruals dengan persamaan regresi linear sederhana atau Ordinary Least Square (OLS) dengan persamaan:

$$
\text { TAC } \left._{\mathrm{i} t} / \mathrm{A}_{\mathrm{t}-1}=\alpha_{1}\left(1 / \mathrm{A}_{\mathrm{t}-1}\right)+\alpha_{2}\left\{\left(\Delta \mathrm{REV}-\Delta \mathrm{REC}_{\mathrm{t}}\right) / \mathrm{A}_{\mathrm{t}-1}\right)\right\}+\alpha_{3}\left(\mathrm{PPE}_{\mathrm{t}} / \mathrm{A}_{\mathrm{t}-1}\right)+\mathrm{e}
$$

\section{Keterangan:}

$\mathrm{TAC}_{\text {it }} \quad$ : Total akrual perusahaan i pada tahun $\mathrm{t}$

$\mathrm{A}_{\mathrm{t}-1} \quad$ : Total aset pada periode $\mathrm{t}$ dikurangi tahun sebelumnya

$\triangle \mathrm{REV}_{\mathrm{t}} \quad$ : Pendapatan periode $\mathrm{t}$ dikurangi dengan pendapatan periode $\mathrm{t}-1$

$\triangle \mathrm{REC}_{\mathrm{t}} \quad$ : Piutang periode $\mathrm{t}$ dikurangi periode $\mathrm{t}-1$

$\mathrm{PPE}_{\mathrm{t}} \quad$ : Aktiva tetap (gross property, plant, and equipment) pada periode $\mathrm{t}$

e : Error term perusahaan i pada tahun $\mathrm{t}$

$\alpha_{1}, \alpha_{2}, \alpha_{3}:$ Firm-specific parameters

3. Menghitung nondiscretionary accruals model (NDA) adalah sebagai berikut:

$$
\mathrm{NDA}_{i t}=\alpha_{1}\left(1 / A_{i t-1}\right)+\alpha_{2}\left(\left(\Delta R E V_{i t}-\Delta R E C_{t}\right) / A_{i t-1}\right)+\alpha_{3}\left(P P E i i t / A_{i t-1}\right)
$$

\section{Keterangan:}


NDAit : nondiscretionary accruals pada tahun $\mathrm{t}$

$\alpha \quad$ : fitted coefficient yang diperoleh dari hasil regresi pada perhitungan total accruals

4. Menghitung discretionary accrual:

$$
\text { DAC }_{i t}=\left(\text { TAC }_{i t} / A_{i t-1}\right)-\text { NDA }_{i t}
$$

Keterangan:

$\mathrm{DAC}_{\mathrm{it}}$ : discretionary accruals perusahaan i pada periode $\mathrm{t}$

\section{Variabel Independen}

\section{Perencanaan Pajak}

Perencanaan pajak adalah suatu tindakan yang bertujuan untuk meminimumkan kewajiban pajak dengan cara merekayasa laporan keuangan agar dapat ditekan serendah mungkin. Variabel perencanaan pajak dapat diukur dengan menggunakan rumus tax retention rate (tingkat retensi pajak), yaitu dimana menganalisis suatu ukuran dari efektifitas manajemen pajak pada laporan keuangan pada tahun berjalan (Wild et al.,2004) dalam (Aditama dan Purwaningsih, 2012).

$$
\text { TRR }=\frac{\text { Net Income }_{i t}}{\text { pretax income }(E B I T)_{i t}}
$$

Keterangan :

TRRit : Tax Retention Rate (tingkat retensi pajak) perusahaan $\mathrm{i}$ pada tahun $\mathrm{t}$

NET INCOMEit : Laba bersih perusahaan i pada tahun $\mathrm{t}$

PRETAX INCOME : laba sebelum pajak perusahaan i pada tahun $t$ (EBITit).

Kecakapan Manajerial

Kecakapan manajerial adalah tingkat keefisienan relatif sebuah perusahaan dalam mengelola input-input (faktor-faktor sumber daya dan operasional) untuk meningkatkan output (penjualan) (Isnugrahadi dan Kusuma: 2009).

Kecakapan manajerial diukur dengan DEA (Data Envelopment Analysis) yang dinyatakan dalam Decision Making Unit atau Unit Kegiatan Ekonomi (UKE) (Isnugrahadi dan Kusuma, 2009). Metode DEA dibuat sebagai alat bantu untuk evaluasi kinerja suatu aktivitas dalam sebuah unit entitas. Pada dasarnya prinsip kerja model DEA adalah membandingkan data input berbobot dan output berbobot dari suatu organisasi atau perusahaan (decision making unit) dengan data input berbobot dan output berbobot lainnya pada decision making unit yang sejenis. Perbandingan ini dilakukan untuk mendapatkan suatu nilai efisiensi. Efisiensi merupakan salah satu parameter pengukuran kinerja sebuah organisasi.

Kecakapan manajerial dalam penelitian ini didefinisikan sebagai tingkat keefisienan relatif sebuah perusahaan dalam mengelola input-input (faktor-faktor sumber daya dan operasional) untuk meningkatkan output(penjualan). Tingkat keefisienan relatif ini kemudian disimpulkan sebagai hasil dari kecakapan manajer. Semakin efisien sebuah perusahaan dibanding dengan perusahaan lainnya dalam sub sektor industri yang sama, maka semakin cakap manajer yang berada di perusahaan tersebut (Isnugrahadi dan Kusuma, 2009).

Dalam penelitian ini untuk mengukur variabel kecakapan manajerial yang menggunakan metode DEA digunakan input dan output sebagai berikut :

Input : 
Item - item yang dijadikan input dikelompokkan menjadi dua faktor yaitu faktor sumber daya (total aset dan jumlah tenaga kerja) dan faktor operasional (Days Cost Of Good Sold in Inventory dan Days Sales Outstanding)

1. Jumlah Tenaga Kerja

Jumlah tenaga kerja adalah faktor sumber daya yang berperan dalam menghasilkan penjualan. Secara umum, untuk nilai penjualan yang tertentu, semakin kecil jumlah tenaga kerja untuk menghasilkan penjualan tersebut maka semakin efisien perusahaan tersebut.

2. Total Aset

Total aset dimasukkan sebagai input karena aset merupakan faktor sumber daya yang sangat penting dalam menghasilkan penjualan (output). Seorang manajer yang cakap akan mampu mengelola besaran aset yang diperlukan untuk menghasilkan penjualan yang maksimal.

\section{Days Cost Of Good Sold in Inventory (DCI)}

DCI mengukur besaran kecepatan perputaran sediaan perusahaan dalam satuan hari. Semakin kecil waktu (hari) yang diperlukan untuk perputaran persediaan maka semakin efisien perusahaan tersebut. Manajer yang cakap diharapkan mampu mengambil langkah langkah yang diperlukan untuk meminimalkan besaran DCI ini.

Rumus untuk menghitung besaran DCI adalah sebagai berikut :

$$
D S I=\frac{365}{\left(\frac{\text { COGS }}{\text { Inventory }}\right)}
$$

\section{DSO (Days Sales Outstanding)}

DSO digunakan untuk mengukur waktu yang diperlukan perusahaan untuk mendapatkan kas setelah melakukan penjualan. Perusahaan yang dapat memperoleh kas kembali semakin cepat menunjukkan pengelolaan perusahaan oleh manajer yang cakap. Rumus untuk menghitung DSO adalah:

$$
\text { DSO }=\frac{\text { Recaivable }}{\left(\frac{\text { Sales }}{365}\right)}
$$

Input-input diatas akan membentuk suatu persamaan :

$$
\text { Total Input }=\text { Total Aset }+ \text { Jumlah Tenaga Kerja }+ \text { DCI }+ \text { DCO }
$$

Output:

1. Penjualan

Penjualan digunakan sebagai output karena penjualan merepresentasikan nilai nominal dari produk perusahaan yang merupakan output mendasar dari perusahaan. Model yang digunakan untuk menghitung efisiensi dengan pendekatan DEA adalah sebagai berikut :

$$
M A X \theta=\frac{\sum_{I}^{s}-1 U_{i} Y_{i k}}{\sum_{j}^{m}-1 V_{j} X_{j k}}
$$

Keterangan:

$\theta$ : nilai efisiensi perusahaan $\mathrm{k}$

$\mathrm{Ui}$ : bobot output i yang dihasilkan perusahaan $\mathrm{k}$

Yik : jumlah output $\mathrm{i}$ dari perusahaan $\mathrm{k}$ dan dihitung dari $\mathrm{i}=1$ hingga $\mathrm{s}$ 
$\mathrm{Vj} \quad$ : bobot $\mathrm{j}$ yang digunakan dalam perusahaan

$\mathrm{Xjk}$ : jumlah input $\mathrm{j}$ dari perusahaan $\mathrm{k}$ dan dihitung dari $\mathrm{j}=1$ hingga $\mathrm{m}$

NIilai efisiensi tidak melebihi $1(100 \%)$ dan input serta output yang dianalisis harus positif. Dengan kata lain, perusahaan tidak melakukan pemborosan sumber daya jika bernilai $1(100 \%)$, sebaliknya jika nilainya $0 \leq \frac{\text { Total Output }}{\text { Total Input }}<1$, maka perusahaan dinilai inefisien dalam mengelola sumber daya perusahaan yang tersedia.

Dalam penelitian ini untuk mempermudah perhitungan efisiensi dengan pendekatan DEA, peneliti menggunakan software DEAP versi 2.1.

\section{Teknik Analisis Data dan Pengujian Hipotesis}

Dalam Penelitian ini, metode analisi yang digunakan yaitu metode regresi linear berganda dengan model sebagai berikut:

$$
\begin{array}{ll}
\mathrm{Y}=\alpha+\beta_{1} \mathrm{X}_{1}+ & \beta_{2} \mathrm{X}_{2}+\mathrm{e} \\
\text { Keterangan : } & \\
\mathrm{Y} & =\text { Manajamen Laba } \\
\alpha & =\text { Konstanta } \\
\beta_{1}-\beta_{2} & =\text { Koefisien regresi } \\
\mathrm{X}_{1} & =\text { Perencanaan Pajak } \\
\mathrm{X}_{2} & =\text { Kecakapan Manajerial } \\
\mathrm{e} & =\text { error }
\end{array}
$$

Pengujian regresi linier berganda dapat dilakukan setelah model dari penelitian ini memenuhi syarat-syarat yaitu lolos dari asumsi klasik meliputi uji normalitas, uji multikoleniaritas, uji heteroskedastisitas dan uji autokorelasi.

Untuk menguji hipotesis dalam penelitian ini digunakan uji signifikansi parameter individual (uji t) dan uji signifikansi simultan (uji f).

\section{Analisis Data dan Pembahasan Hasil Penelitian Hasil Statistik Deskriptif}

\section{Tabel 4.1}

Hasil analisis deskriptif

\begin{tabular}{lrrrrr}
\hline & N & \multicolumn{1}{c}{ Minimum } & Maximum & Mean & Std. Deviation \\
\hline Manajemen Laba & 50 & $-0,19$ & 0,25 & 0,0147 & 0,08236 \\
Perencanaan Pajak & 50 & 0,25 & 2,07 & 0,7719 & 0,29900 \\
Kecakapan & 50 & 0,30 & 1,00 & 0,8915 & 0,19522 \\
Manajerial & & & & \\
Valid N (listwise) & 50 & & & & \\
\hline
\end{tabular}

Sumber: Output SPSS 20, data diolah 2017

Tabel 4.1 menunjukkan hasil analisis berdasarkan perolehan data diketahui bahwa jumlah data $(\mathrm{N})$ dari penelitian ini adalah 50 data. Dari 50 data tersebut, variabel manajemen laba memiliki nilai minimal sebesar $-0,19$ dan maksimal sebesar 0,25 , dengan nilai rata-rata sebesar 0,0147. Sedangkan untuk standar deviasi manajemen laba sebesar 0,08236 yang menunjukkan variasi dalam variabel terdapat perubahan laba dalam setiap periode. Pada variabel perencanaan pajak, nilai minimal sebesar 0,25 dan nilai maksimum sebesar 2,07, nilai rata-rata sebesar 0,7719 dengan standar deviasi sebesar 0,29900. Kemudian variabel kecakapan manajerial memiliki nilai minimal sebesar 0,30 dan nilai maksimal sebesar 1,00, dengan nilai rata-rata sebesar 0,8915 dan standar deviasi sebesar 0,19522. 


\section{Hasil uji Regresi Linear Berganda}

Setelah dilakukan pengujian, model ini lulus dari uji asusmsi klasik, sehingga model ini dapat dilanjutkan pengujian ketahap berikutnya yaitu regresi berganda. Hasil regresi berganda tersebut terlihat seperti pada tabel 4.2 dibawah ini.

Tabel 4.2

Hasil regresi berganda

\begin{tabular}{lccllc}
\hline Model & $\begin{array}{c}\text { Unstandardiz } \\
\text { ed } \\
\text { Coefficients }\end{array}$ & $\begin{array}{c}\text { Standardize } \\
\text { Coefficients }\end{array}$ & T & Sig. \\
\cline { 2 - 4 } & B & $\begin{array}{c}\text { Std. } \\
\text { Error }\end{array}$ & Beta & & \\
\hline (Constant) & 0,002 & 0,066 & & 0,025 & 0,980 \\
Perencanaan Pajak & 0,084 & 0,038 & 0,304 & 2,190 & 0,034 \\
Kecakapan & $-0,058$ & 0,059 & $-0,137$ & $-0,987$ & 0,329 \\
Manajerial & & & & & \\
\hline
\end{tabular}

Sumber: Output SPSS 20, data diolah 2017

Berdasarkan tabel 4.2 dapat diketahui persamaan regresi yang terbentuk adalah sebagai berikut:

$$
\mathrm{ABSDACC}_{\mathrm{t}}=0,002+0,084 \text { TAXPLAN }-0,058 \mathrm{KM}
$$

1. Persamaan regresi linier berganda yang terdapat pada tabel diatas menunjukan bahwa nilai konstanta $(\alpha)$ sebesar 0,002 artinya jika Perencanaan Pajak dan Kecakapan Manajerial nilainya 0 (nol) maka besarnya Manajemen Laba adalah sebesar 0,002.

2. Nilai koefisien Perencanaan Pajak sebesar 0,084 berarti bahwa, apabila semua variabel ditidak adakan kecuali nilai Perencanaan Pajak. Maka nilai Manajemen Laba naik sebesar 0,084 .

3. Nilai koefisien Kecakapan Manajerial sebesar -0,058 berarti bahwa, apabila semua variabel ditidak adakan kecuali nilai Kecakapan Manajerial. Maka nilai Manajemen Laba turun sebesar $-0,058$.

\section{Hasil Pengujian Hipotesis \\ Uji Statistik T (Parsial)}

Uji T ini pada dasarnya menunjukkan seberapa jauh pengaruh satu variabel bebas secara individual dalam menerangkan variasi variabel terikat. Uji $\mathrm{T}$ bertujuan untuk mengetahui pengaruh variabel independen yang terdiri dari Perencanaan Pajak, dan Kecakapan Manajerial terhadap Manajemen Laba pada perusahaan Pertambangan terdaftar di Bursa Efek Indonesia (BEI) tahun 2011-2015.

Tabel 4.3.

Hasil Uji Statistik

\begin{tabular}{lrr}
\multicolumn{3}{c}{ Coefficients $^{\mathbf{a}}$} \\
\hline Model & \multicolumn{1}{c}{ S } & \\
\hline (Constant) &, 025 &, 980 \\
Perencanaan Pajak & 2,190 &, 034 \\
Kecakapan &,- 987 &, 329 \\
Manajerial & & \\
\hline
\end{tabular}

(Sumber: Output SPSS 20, data diolah 2017 


\section{Pengaruh Perencanaan Pajak Terhadap Manajemen Laba}

Berdasarkan hasil dalam penelitian dalam table 4.3 menunjukkan bahwa variabel perencanaan pajak yang di ukur dengan TRR (Tax Retention Rate) berpengaruh signifikan terhadap manajemen laba yang ditunjukkan dengan nilai signifikasi sebesar 0,034 < 0,05. Hasil tersebut berhasil mendukung $\mathrm{H}_{1}$ yang telah diajukan sebelumnya atau dapat dikatakan bahwa hipotesis diterima. Ini berarti bahwa semakin tinggi perencanaan pajak maka semakin besar peluang perusahaan melalukan manajemen laba.

Hasil ini sejalan dengan penelitian sebelumnya yang dilakukan oleh Christina Ranty Sumomba dan YB. Sigit Hutomo (2010), Dewa Ketut Wira Santana dan Made Gede Wirakusuma (2016) yang menyatakan bahwa perencanaan pajak berpengaruh signifikan terhadap manajemen laba. Hal ini dikarenakan berubahnya tarif $\mathrm{PPh}$ badan dapat mempengaruhi perilaku perusahaan dalam mengelola keuangannya dengan memperkecil jumlah laba kena pajak, sehingga perusahaan dapat menekan jumlah pajak yang dibayarkan.

\section{Pengaruh Kecakapan Manajerial Terhadap Manajemen Laba}

Berdasarkan hasil dalam penelitian dalam table 4.3 menunjukkan bahwa variabel kecakapan manajerial yang di ukur dengan DEA (Data Envelopment Analysis) tidak berpengaruh signifikan terhadap manajemen laba yang ditunjukkan dengan nilai signifikasi sebesar 0,329>0,05, maka dapat disimpulkan $\mathrm{H}_{2}$ ditolak yang artinya Kecakapan Manajerial tidak berpengaruh signifikan terhadap Manajemen Laba.

Hasil ini sejalan dengan penelitian sebelumnya yang dilakukan oleh Herlina (2014) yang menyatakan bahwa kecakapan manajerial tidak berpengaruh signifikan terhadap manajemen laba. Hal ini di karenakan manajer yang cakap merupakan faktor kesuksesan bagi perusahaan. Manajer yang cakap tidak membutuhkan manajemen laba untuk memperbagus laba. Manajer yang cakap mampu mengambil keputusan-keputusan ekonomi yang tepat dan mampu mencapai tingkat efisiensi yang tinggi dalam mengelola sumber daya perusahaan karena mereka memiliki pengalaman dan tingkat pendidikan yang cukup tinggi. Dengan mencapai tingkat efisiensi yang tinggi, perusahaan akan meraih laba yang optimal. Manajer yang cakap akan lebih mempertimbangkan untuk terus meningkatkan kualitas kinerjanya dengan menggunakan sumber daya secara tepat sehingga akan memberi nilai tambah bagi perusahaan, daripada harus melakukan manajemen laba yang berisiko gagal mempertahankan kepercayaan publik dan stakeholder.

Namun hasil ini tidak sejalan dengan penelitian yang dilakukan oleh Indra Isnugrahadi dan Indra Wijaya Kusuma (2009) dan Puspita dan Kusumaningtyas, (2017).

\section{Uji Statistik F (Simultan)}

Uji $\mathrm{F}$ bertujuan untuk mengetahui pengaruh variabel independen yang terdiri dari Perencanaan Pajak dan Kecakapan Manajerial terhadap Manajemen Laba secara simultan atau bersama-sama.

Tabel 4.4

Hasil Uji Statistik

\begin{tabular}{rrrrrrr}
\multicolumn{8}{c}{ ANOVA $^{\text {a }}$} & & \\
\hline & & $\begin{array}{c}\text { Sum of } \\
\text { Squares }\end{array}$ & Df & Mean Square & F & Sig. \\
\hline 1 Regression &, 042 & 2 &, 021 & 3,442 &, $040^{\mathrm{b}}$
\end{tabular}




\begin{tabular}{cccc}
$\begin{array}{l}\text { Residual } \\
\text { Total }\end{array}$ &, 290 & 47 &, 006 \\
(Sumber: Output SPSS & 20, data diolah 2017) & \\
\hline Sum &
\end{tabular}

Berdasarkan hasil table 4.4 dalam penelitian ini menunjukkan bahwa variabel perencanaan pajak dan kecakapan manajerial berpengaruh secara simultan berpengaruh terhadap manajemen laba yang ditunjukkan dengan nilai signifikasi $0,040<0,05$. Hasil tersebut berhasil mendukung $\mathrm{H}_{3}$ yang telah diajukan sebelumnya atau dapat dikatakan bahwa hipotesis diterima.

\section{Simpulan dan Saran}

Semakin tinggi perencanaan pajak maka semakin besar peluang perusahaan melalukan manajemen laba. Hal ini dikarenakan berubahnya tarif $\mathrm{PPh}$ badan dapat mempengaruhi perilaku perusahaan dalam mengelola keuangannya dengan memperkecil jumlah laba kena pajak, sehingga perusahaan dapat menekan jumlah pajak yang dibayarkan. Kecakapan manajerial tidak berpengaruh terhadap manajemen laba hal ini dikarenakan Manajer yang cakap tidak membutuhkan manajemen laba untuk memperbagus laba. Manajer yang cakap mampu mengambil keputusan-keputusan ekonomi yang tepat dan mampu mencapai tingkat efisiensi yang tinggi dalam mengelola sumber daya perusahaan sehingga memperoleh laba yang maksimal. Bagi peneliti selanjutnya perlu memilih sampel pada perusahaan lain untuk meningkatkan daya uji empiris tentang Pengaruh Perencanaan Pajak, dan Kecakapan Manajerial Terhadap Manajemen Laba. Bagi peneliti selanjutnya diharapkan dapat menambah periode yang akan dijadikan sampel untuk diteliti karena semakin lama interval waktu pengamatan semakin besar pula kesempatan untuk memperoleh informasi yang handal untuk melakukan penilaian yang akurat.Bagi investor atau calon investor yang akan menambahkan investasinya agar dapat menganalisa laporan keuangan perusahaan sebelum menanamkan investasinya agar tidak tertipu dengan kasus manipulasi laba.

\section{DAFTAR PUSTAKA}

Aditama, F., \& Purwaningsih, A. (2014). Pengaruh Perencanaan Pajak Terhadapa Manajemen Laba Pada Perusahaan Nonmanufaktur Yang Terdaftar Di Bursa Efek Indonesia. Jurnal Akuntansi, 26(1), 1-15.

Demerjian, P., B. Lev, dan S. McVay. (2006). Managerial ability and accruals quality. Working paper. Stem School of Business

Fadhlize. Meihendri. Darmayanti, Yeasy. (2014) "Pengaruh Perencanaan Pajak Dan Aktiva Pajak Tangguhan Terhadap Manajemen Laba Pada Perusahaan Manufaktur Yang Terdaftar Di Bursa Efek Indonesia Tahun 2009-2013”. Jurnal Akuntansi Universitas Bung Hatta.

Herlina. (2014). "Pengaruh Kecakapan Manajerial Terhadap Manajemen Laba Dengan Kepemilikan Manajerial Sebagai Variabel Pemoderasi”. Jurnal akuntansi.

Isnugrahadi, Indra. Kusuma, Indra Wijaya. (2009). "Pengaruh Kecakapan Managerial Terhadap Managemen Laba Dengan Kualitas Auditor Sebagai Variabel Pemoderasi”. Jurnal akuntansi. Universitas Sriwijaya. 
Puspita, E., \& Kusumaningtyas, D. (2017). Pengaruh Mekanisme Kepemilikan Manajerial, Kecakapan Manajerial, Tingkat Pengungkapan Laporan Keuangan Terhadap Manajemen Laba Dengan Kualitas Audit Sebagai Variabel Intervening, 31-35. Retrieved from http://ojs.unpkediri.ac.id

Santana, D. K. W., \& Wirakusuma, M. G. (2016). Pengaruh Perencanaan Pajak, Kepemilikan Manajerial dan Ukuran Perusahaan terhadap Praktek Manajemen Laba. E-Jurnal Akuntansi Universitas Udayana, 14(3), 1555-1583.

Suandy, Early. 2003. Perencanaan Pajak. Jakarta: Salemba Empat

Sumomba, Christina Ranty. (2010). "Pengaruh Beban Pajak Tangguhan Dan Perencanaan Pajak Terhadap Manajemen Laba”. Jurnal akuntansi Universitas Atma Jaya Yogyakarta. Vol 16. No. (2). 103-115

Ulfah, Y. (2013). Pengaruh Beban Pajak Tangguhan dan Perencanaan Pajak terhadap Praktik Manajeman Laba. Journal of Chemical Information and Modeling, 53(9), 1689-1699. https://doi.org/10.1017/CBO9781107415324.004

Wijaya, Maxson dan Martani, Dwi. 2011. Praktik Manajemen Laba Perusahaan Dalam Menanggapi Penurunan Tarif Pajak Sesuai UU No. 36 Tahun 2008. Simposium Nasional Akuntansi XIV Aceh 2011 